\title{
THE POLITICS OF MULTICULTURAL CITIZENSHIP: \\ Problems, Challenges and Prospects of Civil Religion Institutionalization in Indonesia
}

\author{
Masdar Hilmy \\ State Islamic University, Sunan Ampel Surabaya \\ Email: masdar.hilmy@gmail.com
}

\begin{abstract}
This paper analyses how the issue of multicultural citizenship and civil religion has been practiced and debated in Indonesia from political perspective. The writer argues that multicultural citizenship is closely associated with civil religion, in the sense that the latter is the way to objectify and strengthen the earlier. The problem is that the more civil religion is routinized and objectified in daily life, the less the sense of the sacred is. As soon as religion has widely been practiced by members of the society, it soon becomes secular, losing its religious sense since it entangles with local culture. Therefore, objectifying and mainstreaming civic religion must be accompanied by keeping its religious arguments in order to give the civil religion sense of the sacred. As a multicultural country, Indonesia has long acknowledged multicultural citizenship. Sociologically speaking, each Indonesian citizen can live side by side regardless his/her socio-religious background without any discrimination. Indonesian constitution (UUD 1945) clearly states that everyone is equal before the law. Nevertheless, Indonesia's multicultural citizenship soon becomes at stake, especially when political and economic factors interfere into the public sphere.
\end{abstract}

Keywords: multicultural citizenship, civil religion, Indonesian Islam.

\section{Introduction}

As a matter of fact, Indonesia is multicultural in nature. It is also undeniable that Indonesia has the reputation as the 
champion of tolerance and democracy at least in Southeast Asia. This country has undergone some critical situations after the collapse of the New Order regime in 1998. It is the then president BJ Habibie that has unleashed some reformist policies that in turn paved the way for more democratic transition. The result is such a undeniable achievement Indonesia has witnessed four-time general elections peacefully without any chaotic disturbance. Indonesia proves to be able to consolidate its democracy until now. This is praiseworthy and it deserves to be appreciated in the landscape of Indonesia's transition to its fullest-fledged democracy. Not every nation in this world is able to manage itself to be able to survive from the brink of destruction, especially when it faces critical moments of change. Yugoslavia, Russia, and some other Middle-Eastern countries are among the examples of how dealing with transitional politics is not always easy. They are torn part into several small countries and some are trapped in protracted conflicts and civil war.

In addition, Indonesia is well-known for its ability to place religion "elegantly" in its appropriate position. Despite the fact that Indonesia is the largest-Muslim majority in the world, it is not an Islamic state. Indonesia is neither a secular one, in the sense that the country accommodates religion in the formal structure of the State. For example, Indonesia acknowledges some religion-derived national holidays such as Idul Ftri signifying the end of Ramadhan month for Muslims, Christmas day, the birthday of the Prophet Muhammad, Nyepi (Hindu holiday), Waisak (Buddhist holiday), and some other religion-based holidays. At the institutional level, Indonesia has some institutions to deal with religious affairs, such as the Ministry of Religious Affairs, The Council of Indonesian Muslim Scholars (Majlis Ulama Indonesia/MUI), BAZNAS, GKWJ, and other institutions. All of these prove that religion 
has unique place in Indonesian public life and they take part as the major backbone of Indonesia's pillar of religious tolerance and pluralism.

Despite all the above features, it does not mean that Indonesia does not have any problem at all in terms of its application of citizenship principle. A series of violation of the civic rights and religious conflicts have taken place several times, even though most of them have been successfully terminated. This means that religions in Indonesia to a certain degree have not manifested themselves as civil religions that help every citizen express and articulate his/her civic rights.

This paper tries to analyze how multicultural citizenship in Indonesia has become the contested issue of politics in the realm of public sphere. It mainly argues that multicultural citizenship remains the major challenge to the implementation of civil religion in the country. In so far as the issue of religion is concerned, Indonesia does not have any problem with peaceful coexistence among different religious groups. Nevertheless, it poses some potential threats to the upholding of multicultural citizenship. This is so because the issue of civil religion is not able to base its arguments on religious bases. In other words, the issue of civil religion does not have any strong fundamental from religious arguments.

\section{Socio-historical Roots of Multicultural Citizenship}

As a multicultural country, Indonesia incorporates the acknowledgment of multicultural citizenship into the State's law system. Its constitution (UUD 1945) and other international laws are referred to as a legal basis for the multicultural citizenship. The principle of equality before the law has been accommodated by the hierarchy of Indonesian constitution such as UUD 1945. The Article 27 Verse 1 UUD 1945 states 
that: "everyone is equal before the law" and, in doing so, the government must ensure the implementation of the law without any exception. Indonesia has also ratified the international laws such as The United Nations' Universal Declaration of Human Rights in which each individual is equal regardless his/her religious, ethnicity or nationality backgrounds.

It must be underlined from the outset that the platform of multicultural citizenship in Indonesia is not built from scratch. It has long historical precedence since the age of ancient kingdoms in the Archipelago, such as the ancient Mataram kingdom, Sriwijaya, Majapahit, and some other smaller kingdoms. They have basically laid the foundation of multicultural citizenship for society. Majapahit, for instance, acknowledged the Perdikan land system for non-local citizens fully protected by the State. Perdikan system is the permit given by the pre-colonial rulers to the designated persons to occupy land in particular are under the authority of the rulers. Those persons were exempted from the tax imposed upon the citizens. ${ }^{1}$ Among the persons given the status of Perdikan was Sunan Ampel who was given a Perdikan land in Ampel Denta. Later, Sunan Ampel used the land for spreading and teaching Islam to the local community.

In addition to the Perdikan system, the Majapahit kingdom also let all foreigners come and go, from and to, Trowulan, the capital city of Majapahit. All foreigners and visitors were welcome, not on the basis of their religious identity. In the graveyard of Majapahit, some Muslim corpses were laid down and buried. Brawijaya, one of the kings of Majapahit, also married to a Muslim princess from Campa

1 MC Ricklefs, Polarising Javanese Society (Singapore: National University of Singapore Press, 2007), 49. 
called Dwarawati, the aunty of Sunan Ampel. ${ }^{2}$ The kingdom did not have any xenophobic attitudes towards non-Hindu foreigners. This proves that Majapahit is a cosmopolitan kingdom. Before residing in Ampel Denta, Sunan Ampel was allowed to live in Majapahit for one year together with his two other brothers. ${ }^{3}$ It is reported that the three persons were welcomed and treated well by the king Bwawijaya.

This indicates that the local community in this country has been so multicultural in nature. The encounter of persons from different religious identities has been commonplace in this kingdom. This leads to the syncretic nature in terms of religious life. Temples from different religions stood side-by-side without any conflict. Even though there might be latent tension due to membership contest among different religious communities, it did not lead to manifest and hard conflict. This is possible due to the fact that the local Javanese community was characterized by the tendency of religious heterodoxy. The combination and assimilation between two different religious cultures, therefore, are unavoidable. In the old Javanese tradition, Budha-Shiwa reflects the combination between Hindu and Budha. ${ }^{4}$

Multicultural citizenship is made up from socio-cultural diversity. As long as a particular community is able to maintain its diversity in all aspects of life, multicultural citizenship is about the time to mature. Nevertheless, multicultural

2 Slamet Muljana, Runtuhnya Kerajaan Hindu-Jawa dan Timbulnya Negara-negara Islam di Nusantara (Yogyakarta: LKiS, 2005), 95.

${ }^{3}$ Slamet Muljana, Runtuhnya, 96.

${ }^{4}$ MC Ricklefs, "Six Centuries of Islamization in Java," in Nehemia Levtzion (ed.), Conversion to Islam (New York: Holmes \& Meier Pub, 1979), 100. 
citizenship can only be created through long and perpetual processes where socio-cultural dialectics contributes to the maturity of that society. Diversity alone might not end up with multicultural citizenship. It is the two-way dialectics among the different members of the society that help create the multicultural citizenship. When the multicultural citizenship reaches its maturity, there is no inferiority or superiority complexes in terms of cultural and social values. Each culture and social group in a multicultural society is treated under the same social conduct without discrimination. The failure to treat each of them indifferently will only result in social conflict.

The social conflict, riots or chaos are usually resulted from the inability the State to build a common platform among different groups of society in order to coexist to one another. In this context, economy and political factors are among the most pivotal condition for the making of multicultural citizenship. This is so due to the fact that social conflict can only happen when politics and economy are deployed by particular members of the society as a means to exploit or dominate the others. In modern society like today, all conflicts can be traced from the political economy factors, not from the cultural diversity. Persons with different belief system can coexist regardless their different background in cultural identity and religion. This means that social conflict can lead to the failure of multicultural citizenship in the society. The making of multicultural citizenship necessitates harmony of life in all aspects of life, while harmony will only exist so long as politics and economy are in the state of equilibrium.

In the context of how multicultural citizenship is developed in this country, it is noteworthy that religion becomes a double-edged sword that functions a strengthening force to the construction and practice of multicultural 
citizenship on the one side, and as a weakening force that can undermine it on the side. As a strengthening force, religion contributes to the nurturing tradition of multicultural citizenship that enriches the common understanding among the people of different cultural and religious background about the importance of living together side by side. To this end, the elites of religion are responsible in building the theological foundation of social harmony and coexistence among different people. In building the tradition and existence of multicultural citizenship, the elites of religion are fully aware of the importance of religion as a fertile source for civic engagement and pluralism.

In Indonesia, Muhammadiyah and NU are among the socio-religious organizations that are most responsible in the making of multicultural citizenship in the grass-roots. Both organizations, to a larger extent, prove to be culturally knack at cultivating the belief and optimism in how multicultural citizenship is the best practice to Indonesia, now and in the future. In this context, both have served as the civil society that helps people correctly understand living together side-by-side. Both have also made Indonesian Islam different from its counterparts in most of the Middle-eastern countries. In this context, Hefner rightly argues that Indonesia has its own route to the tradition of democratic civility with the so-called "civil Islam" which differs significantly from the rest of the world. ${ }^{5}$

5 Robert W. Hefner, Civil Islam (Princeton, New Jersey: Princeton University Press, 2000); See also, Robert W. Hefner, "Introduction: Multicultural Citizenship in Malaysia, Singapore, and Indonesia," in Robert W. Hefner (ed.), The Politics of Multiculturalism: Pluralism and Citizenship in Malaysia, Singapore, and Indonesia (Honolulu: Hawai'i University Press, 2001), 1-58. 
Having said all of that, it does not mean that religion always gives positive energy to public life. Instead, at times religion plays its destructive role in undermining the seed of multicultural citizenship through the negative construction of the "other" based on textual justification. It is also the religion that classifies citizenship based on social categories such as the first and the second citizen. In this case, the first citizen only belongs to Muslims, while the non-Muslims are considered as the second citizens. Such a hierarchical category does not help us grasp the comprehensive meaning of citizenship because the concept of citizenship accentuates the nobility of each individual as equal to one another, regardless of religious and social background. Of course the social category is there, as long as it is used to respect and protect the nobility of being human, such as the category of junior and senior citizens. Such a category can be employed to differentiate citizens on the basis of their age and contribution to the country, not on the basis of primordial aspects such as religion and ethnicity.

\section{Paradox of Multicultural Citizenship}

Multicultural citizenship starts from theoretical assumption that everyone is equal before the law, regardless his social status, cultural, ethnic and religious background. Under such a circumstance, everyone must be treated equally without discrimination in the public sphere. This means that multicultural public sphere will have to accommodate everyone with his or her own embedded rights as well as characteristics. To abuse those rights is violation of the law. Therefore, the State must ensure and safeguard the actualization of those rights through the impartial enforcement of law. The State must be able to overcome favoritism in which one is treated differently from one another. 
In reality, however, the impartial law enforcement is always difficult, particularly when vested interests are there. Issues of religion, ethnicity and culture are easily deployed by anybody for political interests. Especially in the context of multicultural democracy such as Indonesia, politicians tend to exploit such issues for gaining support during political contest. This is why in political contests, most politicians become religious in appearance, or at least are in favor of particular cultural group in return for political support. In doing so, they will readily wear religious dress-codes as well as symbols in order to convey particular message to the voters. They will also speak on behalf of common interests as though they understand better the needs of people than any other person on earth. The politicians are mostly knack at speaking with the most common language used in the society.

In some societies, particularly where religious symbols do matter in everyday life, and where most of the voters are not rational, the strategy used by politicians as described above might catch the attention of the public. In this case, people tend to aspire for public leaders being regarded as the carrier of the same religious identity as the voters. The people can be easily trapped by the rhetoric of the politicians with religious arguments. This is so because the voters lose their criticisms, giving up rationality easily to the arguments deployed by the politicians. Their rationality is subdued by the emotive inclination. Under such a condition, rational arguments are overpowered by sentimental sides of their emotion and feeling.

As the voters grow more rationally, however, they tend to be self-reflective and considerate towards anything delivered by politicians. Rational choice becomes the major characteristics of the rational voters. Their acts are in accordance with the calculation of risks and benefits or-using 
Marxian theoretical framework-marginal utility. As democracy moves towards its maturity, it will create more rational voters. When talking about benefit or utility, one should be mindful of lumping material benefit together with non-material one. What is meant by the non-material benefit in this context refers to universal moral values which weigh human dignity more valuable than anything material. In other words, cost-andbenefit calculation does not necessarily mean material gain in Marxian sense. Rather, universal human values can be used as moral judgment in decision-making process by rational voters.

In Indonesia, the issue of multicultural citizenship has not been of the major issue until social conflicts and the antiChinese riots took place during Sukarno's Old Order in April 1966 when a significant number of ethnic Chinese was attacked and some were even expelled from the country. ${ }^{6}$ The same riot occurred again following and in the aftermath of the New Order regime in 1998. The ethnic Chinese, again, was the targeted victim of political turbulence as a result of chaotic political transition from the New Order regime to the so-called reformation era (Era Reformasi). Even though the ethnic Chinese are minority, they benefitted from the economic corrupt policies of the regime. As a result, they received more privileges from the New Order regime compared to the majority local Indonesian community.

${ }^{6}$ Christian Gerlach, Extremely Violent Societies: Mass Violence in the Twentieth-Century World (Cambridge: Cambridge University Press, 2010), 61. The overall anti-Chinese riots both during the Old Order and the New Order regimes have been well-discussed by Jemma Purdey, AntiChinese Violence in Indonesia, 1996-1999 (Singapore: National University of Singapore Press, 2006). 
This political and economy favoritism in turn accumulated jealousy and hatred from the non-ethnic Chinese people. When the regime changed, the ethnic Chinese became the target of riots and violent acts. In Jakarta and elsewhere, they were robbed. Their buildings were burnt down, and many Chinese females were raped. Even though the exact number of casualties was not accurately recorded, some of them fled to overseas such as Singapore and China. Some of them brought with them their assets wherever they fled away. As a result, this riot has brought about devastating effect to the economic life of the country. This is understandable due to the fact that the ethnic Chinese became the backbone of national economy during the New Order regime. This made the economic foundation of the State easily collapse and found it difficult for the State to resume its economic performance.

The controversy of Basuki Tjahaja Purnama or Ahok as a non-Muslim governor who is now running in the Pilkada election of Jakarta becomes a lucid example of how multicultural citizenship in Indonesia is debated and practiced in this country. The controversy accumulates when the issue of religious defamation is accused upon him when he made a sensitive statement during his visit to Kepulauan Seribu. During his visit he said that the verse 51 of Al-Ma'idah is manipulated by particular people in supporting non-Muslim public leaders. His statement then becomes viral and invited public anger. On the $4^{\text {th }}$ of November 2016, a massive rally has been conducted by hundreds of thousand Muslims opposing Ahok's statement and urging the authority to bring his case to justice.

The Ahok case represents how the issue of multicultural citizenship in Indonesia is debated in the public sphere. Indonesia has been widely reputed as the champion of social harmony, tolerance and the compatibility of Islam and 
democracy. This does not mean that Indonesia does not have any challenges with regards to the principle of citizenship in the future. The controversy of Ahok is only one case. When one refers to the survey undertaken by the Wahid Foundation, an alarming sign of multicultural citizenship becomes more worrisome; 59,9 \% out of the 1.520 respondents have hated group. Those who are hated are from non-Muslim background, Chinese background, communism, and others. Out of the 59,9 $\%$, 92,2 does not agree that those hated groups become the public leaders of the country. Some $82,4 \%$ of them does not even agree that those who are hated become their neighbors. ${ }^{7}$

On the surface, the Ahok case might be the case of the defamation of religion. Under the surface, however, the Ahok case represents the complexity of multicultural citizenship in Indonesia. Furthermore, it highlights the contest among Muslims over non-Muslim leadership. This is in line with what Hefner argues that "In Indonesia since the 1990s, there has been a bitter struggle between the mainstream Muslim leadership, which affirms equal rights for all and opposes those who would reduce non-Muslims to second-class status, and a tiny but well-financed Islamist minority vociferously-and at times even violently_opposed to equal rights for Christians and Chinese." 8 By and large, the majority of Indonesian Muslims would not have any objection towards non-Muslim leadership in public as this issue comprises a long-lasting dispute in Islamic theology.

7 Zuly Qodir, "Teologi Politik Jelang Pilkada" Kompas, Saturday, 29 October 2016, p. 7.

${ }^{8}$ Hefner, "Introduction," 11. 


\section{The Closing Remarks: The Failure of Civil Religion Institutionalization?}

The explanation above raises the following question: is the Ahok case indicates the failure of civil religion institutionalization in this country? This is the question to reflect in order to grasp the problems and challenges of multicultural citizenship in Indonesia in the future. Despite the fact that in general Indonesian Muslims do not have any objection whatsoever to the issue of non-Muslim leadership, it does not mean that the issue of multicultural citizenship is fine in this country. When one looks into the deeper structure of the issue of non-Muslim leadership, it reveals an alarming sign of multicultural citizenship in the future. This is one of the big challenges Indonesia is facing now, and there is no ready solution for this problem.

With regard to the issue of multicultural citizenship, I assume that education has not been maximally employed to foster the foundation of multicultural citizenship. It seems that the issues of Pancasila, NKRI, democracy, human rights, and the like are not part of religious discourse and therefore they are all secular. This is so because education, especially Islamic education, fails to give its religious "flavor" to what the society in general assume as secular subjects. The homework for us now is: how to make those issues-multicultural citizenship, social harmony, democracy, Pancasila, NKRI, democracy, human rights, and the like-are an integral part of Islamic teaching? This is not an easy task to do for Indonesia, indeed. 